\title{
Pencegahan Gerakan Radikalisme melalui Penanaman Ideologi Pancasila dan Budaya Sadar Konstitusi Berbasis Komunitas
}

\section{Preventing Radical Movement by Fostering the Ideology of Pancasila and Community-based Constitution Awareness}

\author{
Iwan Satriawan ${ }^{1}$, Muhammad Nur Islami ${ }^{2}$, Tanto Lailam ${ }^{3}$ \\ ${ }^{1,2,3}$ Fakultas Hukum, Universitas Muhammadiyah Yogyakarta \\ Bantul, Daerah Istimewa Yogyakarta \\ 1.
}

Riwayat Artikel: Dikirim 28 Januari 2019; Diterima 8 Mei 2019; Diterbitkan 31 Mei 2019

\begin{abstract}
Abstrak
Pengabdian ini memfokuskan pada upaya pencegahan gerakan radikalisme melalui penanaman ideologi Pancasila dan budaya sadar konstitusi berbasis komunitas. Komunitas yang dipilih adalah Pimpinan Ranting Muhammadiyah Bangunjiwo Barat, Banguntapan IV dan Sidokarto. Persoalan komunitas masyarakat saat ini adalah adanya gerakan-gerakan radikalisme yang memiliki agenda terselubung yang menggerogoti nilai-nilai Pancasila - memecah belah bangsa Indonesia, melemahkan persatuan dan kesatuan - merusak kebhinekaan yang sejak Indonesia berdiri telah menjadi konsensus bersama. Kegiatan ini dilakukan dalam bentuk pengabdian berupa: (1) Pelatihan Pencegahan Radikalisme melalui Penanaman Ideologi Pancasila dan Budaya Sadar Konstitusi yang dilakukan di 3 tempat, yakni: di Pimpinan Ranting Muhammadiyah Bangunjiwo Barat, Banguntapan IV dan Sidokarto. Pelatihan ini memfokuskan pada penguatan pemahaman Pancasila dan budaya sadar konstitusi serta strategi pencegahan radikalisme di Indonesia; (2) ToT Pencegahan Radikalisme melalui Penanaman Ideologi Pancasila dan Budaya Sadar Konstitusi. Training of Trainer ini merupakan lanjutan dari pelatihan pada PRM yang dilakukan sebelumnya. Adapaun materi dalam ToT ini meliputi: Pemahaman Ideologi Bernegara Menurut Muhammadiyah dan Sikap Bernegara Muhammadiyah; Pencegahan Radikalisme melalui Kewajiban Bela Negara dalam kehidupan beragama; Advokasi Kebijakan dan Hukum terkait Gerakan Radikalisme. ToT ini dilakukan agar peserta memiliki kemampuan untuk menjadi pelatih yang memiliki pemahaman dan sikap bahwa radikalisme/ terorisme harus dicegah sedemikian rupa dengan berbagai kegiatan pencegahan. Kegiatan pencegahan tersebut merupakan bentuk bela negara warga negara yang baik demi menjaga kelangsungan hidup bangsa dan negara yang seutuhnya dengan melakukan pencegahan gerakan radikalisme di masing-masing komunitas.
\end{abstract}

Kata kunci: Pancasila, budaya sadar konstitusi, radikalisme, terorisme, pencegahan.

\begin{abstract}
The community service program aims to prevent radicalism movement through inculculating state ideology, Pancasila and building awareness on understanding more about Constitution among the community. In this program, Mubammadiyah branches at some villages in Yogyakarta are selected to be the pilot project. They are Mubammadiyah branch of Sidokarto, Banguntapan IV and Bangunjiwo Barat. These area are considered as some villages that are susceptible for penetrating radicalist movement ideology which threaten the state ideology, Pancasila as the result of national political consensus of Indonesia since 1945. The program is divided into two activities, 1) training for understanding Pancasila and preventing radicalism. The program focuses on how to improve the level of understading of Muhammadiyah actisvits on the phenomena of radicalist movement in the society. The participants are also guided by the understanding Pancasila as the state ideology. 2) Training of Trainers for understanding Pancasila and the 1945 Constitution. This program is more focused on developing the understanding of participants on Pancasila and the 1945 Constitution. The participants are also equipped with basic skill on how to advocate the rights of people in combating radicalism. It is expected that the program educates the Muhammadiyah activists to be the agent of combating radicalism as well as protecting the society.
\end{abstract}

Keywords: Pancasila, constitutional awareness, culture, radicalism, prevention. 


\section{PENDAHULUAN}

Saat ini Indonesia mengalami "krisis ideologi Pancasila" dan "krisis budaya sadar konstitusi."Pancasila dan UUD 1945 saat ini sedang diuji kekokohannya - diuji nilai persatuan dan kesatuannya - diuji nilai keberagamannya. Berbagai persoalan bangsa, negara dan masyarakat ini semakin pelik dengan munculnya gerakan radikalisme di masyarakat, seperti penggunaan atribut dan isu bangkitnya PKI (PKI telah berusaha melakukan kudeta kepada NKRI pada tahun 1948 dan 1965), gerakan bervisi pendirian khilafah (HTI), munculnya gerakan ISIS di Indonesia, penghinaan terhadap Pancasila, penghinaan terhadap agama, penghinaan terhadap bendera negara, tudingan sebagian masyarakat terhadap sebagian masyarakat yang lain sebagai "anti Pancasila". teror kampung melayu, terorisme, dan isu upaya makar terhadap pemerintah.

Persoalan-persoalan

tersebut

bermuara pada ideologi radikalisme yang ingin merubah tatanan bangsa Indonesia yang jelas bertentangan dengan Pancasila. Gerakan radikalisme sebagai suatu faham tidak selalu ditandai dengan aksi-aksi kekerasan, namun dapat juga sebatas ideologi yang tidak menggunakan cara-cara kekerasan (M. Khamdan, 2016:208). Radikalisme yang berkembang di masyarakat dalam bentuk radikalisme ideologi maupun agama harus bisa dicegah. Hal ini diperlukan untuk menciptakan masyarakat yang harmonis. Untuk melakukan upaya dalam pencegahan gerakan radikalisme tidaklah mudah dan membutuhkan strategi yang terstruktur, sistematis dan massif. Untuk itulah, penting adanya pemahaman yang komprehensif tentang gerakan radikalisme dan melakukan pencegahan terhadap gerakan radikalisme terebut melalui penanaman ideologi Pancasila dan budaya sadar konstitusi berbasis komunitas. Kegiagan ini dilksanakan di beberapa Desa di Kabupaten Bantul dan Kabupaten Sleman sebagai komunitas percontohan.

Komunitas masyarakat Desa di Kabupaten Bantul yang dipilih adalah Desa
Bangunjiwo dan Desa Banguntapan, sementara di Kabupaten Sleman dipilih Desa Sidokarto. 3 (tiga) desa ini dipilih karena beberapa alasan, yaitu: (1) desa tersebut memiliki pendukuk yang sangat heterogen (jumlah pendatang yang sangat besar), sehingga masuknya gerakan radikalisme bisa lebih cepat; (2) Desa Bangunjiwo dan Desa Banguntapan pernah menjadi salah satu daerah markas bagi organisasi Gerakan Fajar Nusantara (Gafatar/ metamorvosis Al Qiyadah Al Islamiyah) yang kemudian dinyatakan sebagai organisasi terlarang oleh Majelis Ulama Indonesia; (3) di Desa Bangunjiwo, Desa Banguntapan dan Desa Sidokarto pernah muncul gerakan dan simbol ISIS beberapa tahun lalu sebelum ISIS dinyatakan organisasi terlarang; (4) banyaknya pengajian bervisi khilafah yang dilakukan oleh Hizbut Tabrir Indonesia (HTI), bahkan menjadi basis pengkaderan; (5) di desa tersebut, akhirakhir ini muncul gerakan dan simbol bangkitnya komunisme di masyarakat (PKI baru).

Komunitas/mitra yang dipilih di desa tersebut adalah komunitas organisasi ranting Muhammadiyah. Dipilihnya komunitas ranting Muhammadiyah tersebut dilatarbelakangi oleh komitmen dan tanggung jawab Muhammadiyah secara keseluruhan untuk menangkal gerakan radikalisme dan terorisme di Indonesia. Dalam pengabdian ini komunitas Muhammadiyah yang dipilih adalah adalah (1) Pimpinan Ranting Muhammadiyah (PRM) Bangunjiwo Barat - Desa Bangunjiwo, Pimpinan Ranting Muhammadiyah Banguntapan IV - Desa Banguntapan, dan Pimpinan Ranting Muhammadiyah - Desa Sidokarto.

Komunitas ini merupakan bagian dari organisasi Muhammadiyah yang jelas menyatakan bahwa Pancasila adalah satusatunya ideologi dalam NKRI dan selama ini PRM memiliki peranan dalam pencegahan gerakan radikalisme di tengah masyarakat. PRM ini merupakan komunitas induk yang di dalamnya juga ada PR Aisyiyah 
(komunitas perempuan), PR Pemuda Muhammadiyah (komunitas Pemuda), PR Nasyiatul Aisyiyah (komunitas Perempuan Muda), Komando Kesiapsiagaan Angkatan Muda Muhammadiyah (Kokam), artinya komunitas yang dipilih mewakili lintas generasi baik termasuk di dalamnya perempuan dan pemuda. Artinya komunitas ini telah memiliki komitmen dalam pencegahan paham radikalisme, namun memiliki keterbatasan pemahaman dan aksi dalam melakukan pencegahan gerakan radikalisme yang berkembang di masyarakat.

\section{METODE}

Tujuan program ini adalah menjadikan mitra (PRM Bangunjiwo Barat, PRM Banguntapan IV dan PRM Sidokarto) sebagai model pencegahan gerakan radikalisme melalui penanaman ideologi Pancasila dan budaya sadar konstitusi berbasis komunitas. Dalam arti pemberdayaan masyarakat (partisipasi aktif) sebagai inti gerakannya, dengan menempatkan mitra sebagai pelaku utama pada setiap tahapan perencanaan, pelaksanaan, dan monitoring - evaluasi program. Pendekatan pemberdayaan (partisipasi aktif) dalam pengabdian ini berprinsip pada kemandirian masyarakat, metode ini bertujuan untuk meningkatkan kapasitas masyarakat dan menguatkan ideologi Pancasila dan budaya sadar konstitusi, sehingga komunitas tersebut dapat mendeteksi - mencegah dan menanggulangi adanya gerakan-gerakan radikalisme secara dini di kalangan masyarakat.

Pemberdayaan masyarakat adalah suatu proses dimana masyarakat mampu meningkatkan pemahamannya secara mandiri. Dalam proses ini, lembaga berperan sebagai fasilitator yang mendampingi proses pemberdayaan masyarakat, yang pada prinsipnya masyarakatlah yang menjadi aktor dan penentu pencegahan gerakan radikalisme melalui penanaman ideologi Pancasila dan budaya sadar konstitusi. Usulan-usulan masyarakat merupakan dasar bagi program. Aspek penting dalam suatu program perberdayaan masyarakat adalah: program dan strategi yang disusun sendiri oleh masyarakat.

Model pendidikan berbasis komunitas yang dikembangkan menitikberatkan pada penguatan kapasitas dan pembentukan kepribadian yang luhur sebagai proses yang membebaskan, yang ke depan akan menjadi simpul relawan penggerak dari berbagai komunitas untuk merawat Pancasila Konstitusi secara benar. Dengan model seperti ini diharapkan pada akhirnya dapat menghasilkan insan kamil yang tidak saja mengerti hak dan kewajiban ideologis konstitusionalnya, tetapi juga sanggup memperjuangkan hak-hak konstitusional tersebut, sanggup bela negara, bahkan memberikan teladan bagi masyarakat di lingkungannya sehingga tercipta masyarakat yang mencerahkan. Beberapa metode yang digunakan dalam pengabdian ini:

1. Pelatihan. Metode pelatihan dilakukan untuk memberikan solusi terhadap persoalan: (1) kekurangpahaman terhadap ideologi Pancasila dan budaya sadar konstitusi sebagai pedoman hidup berbangsa, bernegara dan bermasyarakat; (2) kekurangan pemahaman gerakangerakan radikalisme yang tumbuh di masyarakat; (3) kekurangpahaman cara dan strategi mendeteksi (menemukan atau melacak) sejak dini adanya gerakangerakan radikalisme di tengah masyarakat; (4) ketidakmampuan mencegah munculnya gerakan radikalisme melalui penanaman Pancasila dan budaya sadar konstitusi yang tumbuh di masyarakat.

Program-program pelatihan dalam pengabdian masyarakat dikembangkan dengan metode yang lebih sederhana, yaitu dengan menyelenggarakan sarasehan dan diskusi santai/informal sehingga masyarakat tidak terlalu berat dalam menerima materi-materi pelatihan. Materi-materi pelatihan yang disampaikan mengambil beberapa kasus 
dan best practice peran masyarakat dalam pencegahan radikalisme di Indonesia, sehingga peserta pelatihan akan memperoleh gambaran-gambaran kasus dan strategi yang seharusnya dilakukan. Selain itu, juga sharing pengalaman merupakan syarat untuk dapat meningkatkan kreativitas dan inovasi masyarakat dan menjadi penentu pelaksanaan kegiatan dalam menciptakan masyarakat yang mandiri (Widjajanti, 2011:25). Metode pelatihan dengan diskusi informal bertujuan untuk mendorong partisipasi dan perhatian peserta yang lebih intens (Kusumasari dan Suyatna, 2015: 21).

2. Pendampingan. Untuk memastikan bahwa program-program pelatihan dapat berkelanjutan, tim pengabdian juga melakukan kegiatan pendampingan dengan pemonitoran dan evaluasi secara rutin. Dalam proses pendampingan ini, tim asistensi juga memberikan solusisolusi atas hambatan yang dihadapi oleh masyarakat melalui komunikasi yang intens. Pendampingan ini dilakukan agar program dapat terlaksana dengan baik atau merupakan penerapan hasil pelatihan yang dilakukan.

3. Tahapan terakhir dari program ini agar program ini berkelanjutan di komunitas dilakukan dengan metode Training of Trainer. Training of Trainer diperuntukkan hanya bagi anggota komunitas terpilih (5 peserta terbaik) yang diharapkan setelah selesai pelatihan mampu menjadi pelatih dan mampu mengajarkan materi pelatihan tersebut kepada orang lain di komunitas tersebut atau berbeda komunitas dengan tambahan materi yaitu: (1) pelatihan keterampilan melatih (training delivery); (2) pelatihan menyusun langkah atau tahapan melatih (session design); (3) Pelatihan keterampilan mendisain kurikulum pelatihan (curriculum design); (4) praktik menjadi pelatih dalam pelatihan.

\section{HASIL DAN PEMBAHASAN \\ Pelaksanaan Pengabdian}

Pelaksanaan pengabdian ini dilakukan dengan berbagai pelatihan di wilayah komunitas PRM Bangunjiwo Barat, PRM Banguntapan IV (Kabupaten Bantul) dan PRM Sidokarto (Kabupaten Sleman), dan kegiatan lanjutan yaitu dilaksanakannya Training of Trainer bagi anggota PRM yang dinilai mampu menjadi oase pengetahuan mengenai radikalisme di komunitas tersebut.

\section{Pelatihan Pencegahan Radikalisme}

Pelatihan Pencegahan Radikalisme dilakukan di PRM Bangunjiwo Barat, PRM Banguntapan IV (Kabupaten Bantul) dan PRM Sidokarto (Kabupaten Sleman). Pelatihan ini bertujuan memberikan pemahaman kepada komunitas masyarakat mengenai gerakan radikalisme di Indonesia, indikasi gerakan radikalisme di masyarakat, dan langkah-langkah yang dilakukan jika terjadi gerakan radikalisme atau orang-orang yang dicurigai terindikasi gerakan radikalisme.

Pelatihan Pencegahan Radikalisme di komunitas PRM Sidokarto (Kabupaten Sleman) menghadirkan narasumber Bapak Iwan Satriawan, S.H., MCL., Ph.D dan Bapak Dr. Muhammad Nur Islami, S.H., M.Hum yang menyampaikan tentang penyebab gerakan radikalisme di Indonesia dan tata cara pencegahan gerakan tersebut. 
Gambar 1.

Pelatihan Pencegahan Radikalisme melalui Penanaman Ideologi Pancasila dan budaya sadar Konstitusi di PRM Sidokarto

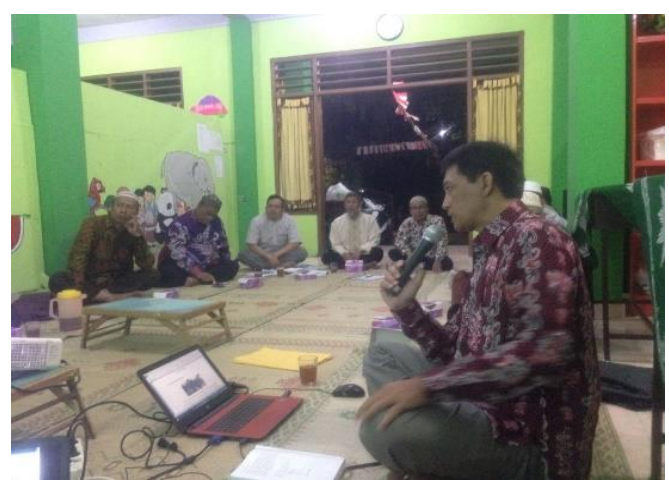

Pelatihan Pencegahan Radikalisme di PRM Banguntapan IV (Kabupaten Bantul) menghadirkan narasumber Bapak Dr. Muhammad Nur Islami, S.H., M.Hum dan Bapak Iwan Satriawan, S.H., MCL., Ph.D

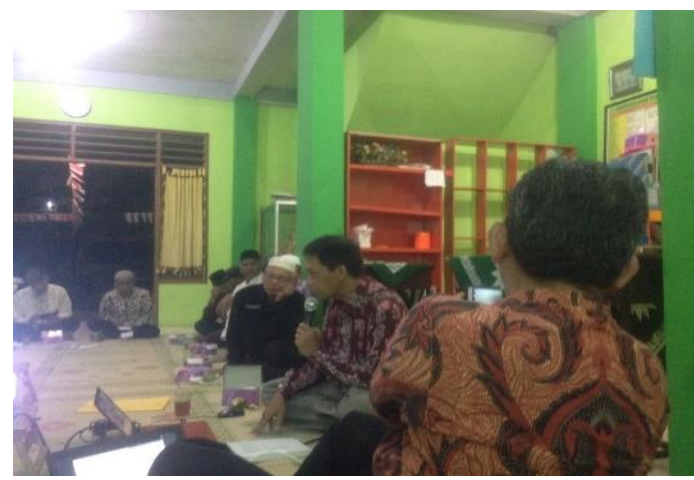

yang menyampaikan tentang penyebab gerakan radikalisme di Indonesia dan langkah-langkah yang dilakukan jika komunitas menghadapi langsung di masyarakat.

Gambar 2.

Pelatihan Pencegahan Radikalisme melalui Penanaman Ideologi Pancasila dan budaya sadar Konstitusi di PRM Banguntapan IV

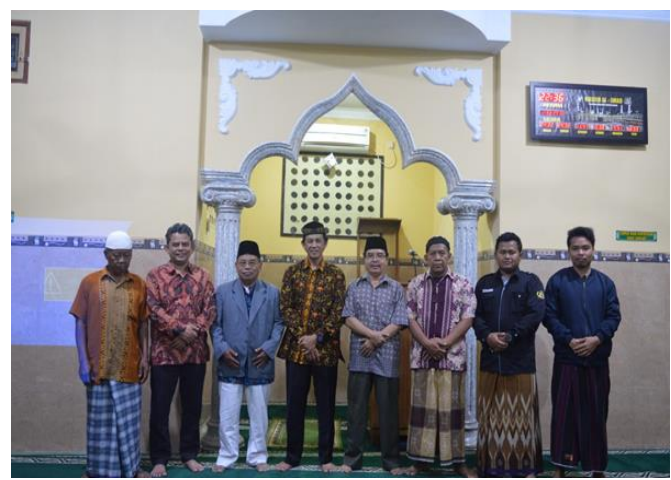

Pelatihan Pencegahan Radikalisme di PRM Bangunjiwo Barat (Kabupaten Bantul) menghadirkan narasumber Bapak Dr. Muhammad Nur Islami, S.H., M.Hum dan

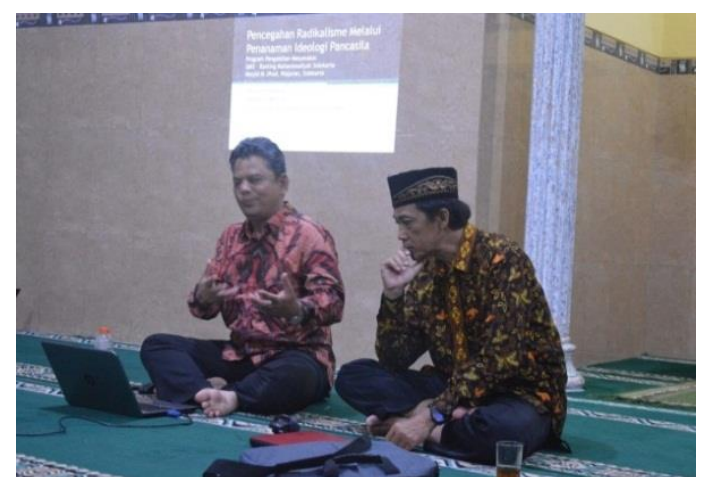

Bapak Tanto Lailam, S.H., LL.M. yang menyampaikan tentang penyebab gerakan radikalisme di Indonesia dan langkahlangkah yang dilakukan. 
Gambar 3.

Pelatihan Pencegahan Radikalisme melalui Penanaman Ideologi Pancasila dan budaya sadar Konstitusi di PRM Bangunjiwo Barat

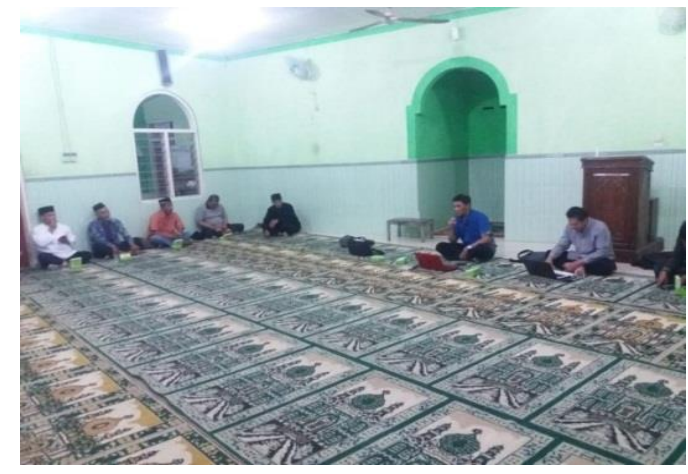

Beberapa hal yang disampaikan dalam pelatihan tersebut, yaitu:

a. Potensi radikalisme yang ditentukan oleh persepsi individu tentu tidak hanya dipengaruhi suatu landasan ideologi tertentu, namun dapat juga dipengaruhi oleh beragam faktor lain dalam isu global, regional, maupun lokalitas (Hilmy, 2015: 407). Namun aksi-aksi radikalisme (seperti terorisme) juga dilandasi adanya pemahaman ideologi yang radikal, artinya radikalisme itu bisa dalam bentuk ideologi yang bertentangan dengan Pancasila atau dalam bentuk aksi yang merusak tatanan masyarakat. Potensi berpikir, bersikap dan bertindak radikal, berideologi radikal (radikalisme) dan tumbuh reaktif menjadi radikal (radikalisasi) adalah modal awal seseorang menjadi pelaku teror (teroris) atau orang yang berpaham teror (terorisme) (Rohkmad, 2012: 83)

b. Dalam sejarahnya, konsep radikalisme melekat pada ranah politik, yakni sebuah cara pandang yang ekstrem terhadap kekuasaan yang "dikotomis" -menurut istilah Davis (2017) yang dilakukan oleh kelompok yang merasa "tidak nyaman" dengan penguasa, lalu diungkapkannya dalam bentuk "kekerasan".

c. Beberapa gerakan radikalisme yang muncul di masyarakat, misalnya radikalisme yang dibangun berdasar kesamaan ideologi bernegara yang berkembang di Indonesia adalah ideologi

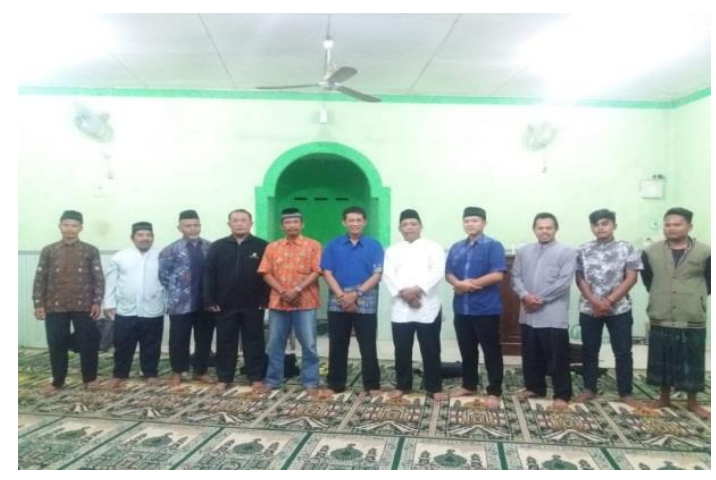

komunis (PKI). Selain itu, juga terdapat radikalisme agama, kondisi ini terjadi akibat adanya politisasi untuk menjadikan agama sebagai tameng demi simpatisan dan dukungan, bahkan aksi terorisme sebagian didasari pemahaman agama yang salah. Radikalisme agama merupakan pemikiran dan tindakan ekstrim yang dilakukan oleh seseorang atau sekelompok orang dengan mengatasnamakan agama (Ninin Prima Damayanti, dkk. 2003: 45), salah satunya ditandai dengan adanya pemahaman masyarakat bahwa kepemimpinan yang cocok untuk Indonesia adalah model khilafah dan syariah dianggap sebagai representasi sistem politik-bernegara autentik yang berasal dari wahyu Tuhan (Ahmad Asrori, 2015: 257).

d. Terorisme adalah tindakan kejahatan terhadap kemanusiaan dan peradaban yang menimbulkan ancaman serius terhadap kedaulatan negara, bahaya terhadap keamanan, perdamaian dunia serta merugikan kesejahteraan masyarakat. Terorisme adalah salah satu bentuk kejahatan yang diorganisasi dengan baik (well organized), bersifat transnasional dan digolongkan sebagai kejahatan luar biasa (extra-ordinary crime) yang tidak membeda-bedakan sasaran (indiskrimatif). Sementara Jihad mengandung dua pengertian: (1). Segala usaha dan upaya sekuat tenaga serta kesediaan untuk menanggung kesulitan 
di dalam memerangi dan menahan agresi musuh dalam segala bentuknya. Jihad dalam pengertian ini juga disebut al-qital atau al-barb. (2). Segala upaya yang sungguh-sungguh dan berkalanjutan untuk menjaga dan meninggikan agama Allah (li i'laai kalimatillab).

e. Perbedaan antara Terorisme dengan Jihad, Terorisme: 1) Sifatnya merusak (ifsad) dan anarkhis / chaos (faudha). 2) Tujuannya untuk menciptakan rasa takut dan/atau menghancurkan pihak lain. 3) Dilakukan tanpa aturan dan sasaran tanpa batas. Semenatra Jihad mengandung pemahaman bahwa: 1) Sifatnya melakukan perbaikan (ishlah) sekalipun dengan cara peperangan. 2) Tujuannya menegakkan agama Allah dan / atau membela hak-hak pihak yang terzhalimi. 3) Dilakukan dengan mengikuti aturan yang ditentukan oleh syari'at dengan sasaran musuh yang sudah jelas.

f. Berdasarkan fatwa Majelis Ulama Indonesia (MUI) bahwa (1) hukum melakukan teror adalah haram, baik dilakukan oleh perorangan, kelompok, maupun negara. Sedangkan hukum melakukan jihad adalah wajib. Bom bunuh diri hukumnya haram karena merupakan salah satu bentuk tindakan keputusasaan (al-ya'su) dan mencelakakan diri sendiri (iblak an-nafs), baik dilakukan di daerah damai (dar al-shulh/dar al-salam /dar al-da'wab) maupun di daerah perang (dar al- 82 harb).

g. Gerakan-gerakan radikalisme ini harus terus diwaspadai, karena memiliki agenda terselubung yang menggerogoti nilai-nilai Pancasila-memecah belah bangsa Indonesia, melemahkan persatuan dan kesatuan - merusak kebhinekaan yang sejak Indonesia berdiri telah menjadi konsensus bersama. Gerakan radikalisme seperti orang-orang yang tergabung di kelompok Negara Islam Suriah dan Irak (ISIS), Gafatar, dan lainnya.

h. Melawan radikalisme tidak hanya bisa dengan kekerasan, karena yang dihadapi adalah masalah paham dan pemahaman, sehingga juga harus ditangani dengan memberikan pemahaman ke jalan yang benar dan diridhoi Allah SWT. Maka, PRM diharapkan dapat mengumpulkan dalil-dalil agama (Islam) yang melarang kekerasan, apalagi membunuh sesama manusia (bahkan sesama muslim). Selain itu, yang terpenting adalah bahwa bagi Indonesia, Pancasila sudah harga mati sebagai ideologi negara dan bangsa, sebagai dasar negara, sebagai falsafah dan pegangan hidup bangsa, sebagai kepribadian bangsa, dan sebagai konsesus dasar bangsa. Pancasila sudah final sebagai ideologi negara sehingga NKRI dengan dasar Pancasila sudah tepat, sudah selesai, sudah tuntas, sudah paripurna, tidak perlu didebatkan lagi. Selain itu, jika melihat adanya gerakan radikalisme di masyarakat, komunitas dapat melakukan pencegahan bersama (mengetahui latar belakang masyarakat yang tinggal di desa, misalnya pada saat menjadi penduduk baru). Komunitas juga dapat bekerjasama dengan pihak Kepolisian atau pihak-pihak lain jika di desa tersebut ada orang-orang yang mencurigakan/terindikasi gerakan radikalisme.

Dengan adanya materi pokok yang disampaikan dalam pelatihan tersebut, komunitas masyarakat dapat mempelajari dan mengkaji gerakan radikalisme secara baik, dan menjadi garda terdepan jika ada indikasi-indikasi gerakan radikalisme di desa tempat tinggalnya.

\section{Training of Trainer Pencegahan Radikalisme melalui Penanaman Ideologi Pancasila dan Budaya Sadar Konstitusi}

Training of Trainer ini merupakan lanjutan dari pelatihan pada PRM yang dilakukan sebelumnya. To $T$ ini menghadirkan narasumber dari Tim Pengabdi: Bapak Iwan Satriawan, S.H., MCL., Ph.D yang menfokuskan pada langkah-langkah pencegahan dan advokasi 
yang strategis ketika menghadapi radikalisme di wilayah komunitas PRM berada dan Bapak Tanto Lailam, S.H., LL.M. menyampaikan hubungan agama dan negara dan pemahaman ideologi bernegara menurut Muhammadiyah. ToT ini dilakukan agar peserta memiliki kemampuan untuk menjadi pelatih dalam agenda dan isu yang sama pada lingkup PRM Bangunjiwo Barat, PRM Sidokarto dan PRM Banguntapan IV.

Gambar 4.

ToT Pencegahan Gerakan Radikalisme

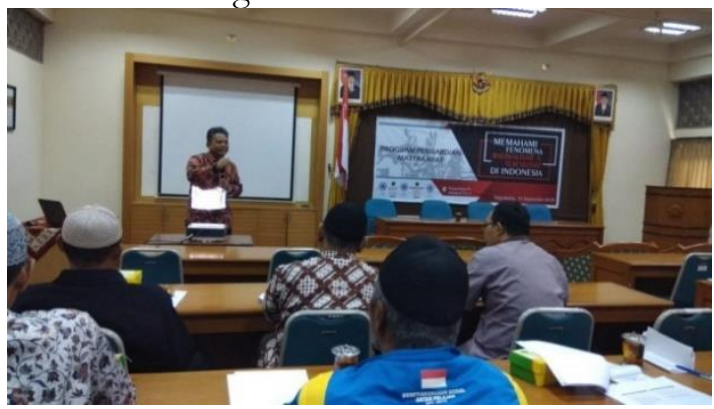

Beberapa point yang disampaikan dalam Training of Trainer tersebut:

a. Pemahaman Ideologi Bernegara Menurut Muhammadiyah

Indonesia bukan negara Islam, tetapi Indonesia merupakan negara muslim (Indonesia sebagai negara yang berpenduduk terbanyak beragama Islam). Sila pertama Pancasila "Ketuhanan Yang Maha Esa" dapat dipahami identik, dengan tauhid yang merupakan inti ajaran Islam, dengan pengertian bahwa dalam ajaran Islam diberikan toleransi, kebebasan, dan kesempatan yang seluas-luasnya bagi pemeluk agama lain untuk melaksanakan ajaran mereka masing-masing.

Pandangan Muhammadiyah bahwa Negara Kesatuan Republik Indonesia (NKRI) yang diproklamasikan 17 Agustus 1945 adalah Negara Pancasila yang ditegakkan di atas falsafah kebangsaan yang luhur dan sejalan dengan ajaran
Islam. Sila Ketuhanan Yang Maha Esa, Kemanusiaan yang adil dan beradab, persatuan Indonesia, Kerakyatan yang dipimpin oleh hikmat kebijaksanaan dalam permusyawaratan/perwakilan, dan Keadilan sosial bagi seluruh rakyat Indonesia; secara esensi selaras dengan nilai-nilai ajaran Islam. Negara Pancasila yang mengandung jiwa, pikiran, dan cita-cita luhur sebagaimana termaktub dalam Pembukaan UUD 1945 itu dapat diaktualisasikan sebagai Baldatun Thayyibatun Wa Rabbun Ghafur yang berperikehidupan maju, adil, makmur, bermartabat, dan berdaulat dalam naungan ridla Allah SWT.

Berdasar pada Tanfidz

Keputusan

Muktamar Muhammadiyah Ke-47 menyebutkan bahwa Negara Pancasila sebagai Dâr Al-Ahdi Wa Al-Syahâdah, negara kesepakatan dan negara kesaksian. Dalam arti bahwa Muhammadiyah memiliki komitmen tinggi dengan negara Pancasila dan siap bersama keluarga bangsa yang lain untuk mengisi negara Pancasila untuk mencapai cita-cita nasional yang telah diletakkan oleh pendiri bangsa ini, yang di dalam Pembukaan UUD 45 berbunyi Negara Indonesia yang merdeka bersatu, berdaulat, adil, dan makmur. Muhammadiyah memberikan tafsir kontekstual terhadap cita-cita nasional ini, untuk menjadi Indonesia yang maju, adil, makmur, berdaulat dan bermartabat (Indonesia berkemajuan). Muhammadiyah berkomitmen untuk terus berjuang memproyeksikan Indonesia menjadi Negara Pancasila yang maju, adil, makmur, bermartabat, 
dan berdaulat dalam lindungan Allah SWT.

Negara Pancasila merupakan hasil konsensus nasional (dâr al-ahdi) dan tempat pembuktian atau kesaksian (dâr al- syahâdab) untuk menjadi negeri yang aman dan damai (dâr al-salâm). Negara ideal yang dicitacitakan Islam adalah negara yang diberkahi Allah karena penduduknya beriman dan bertaqwa (QS Al- A'raf: 96), beribadah dan memakmurkannya (QS Al-Dzariyat: 56; Hud: 61), menjalankan fungsi kekhalifahan dan tidak membuat kerusakan di dalamnya (QS Al-Baqarah: 11, 30), memiliki relasi hubungan dengan Allah (bablun min Allâh) dan dengan sesama (hablun min al-nâs) yang harmonis (QS Ali Imran: 112), mengembangkan pergaulan antar komponen bangsa dan kemanusiaan yang setara dan berkualitas taqwa (QS Al-Hujarat: 13), serta menjadi bangsa unggulan bermartabat (khairu ummah) (QS Ali Imran: 110).

Pancasila sebagai dasar Negara Republik Indonesia adalah ideologi negara yang mengikat seluruh rakyat dan komponen bangsa. Pancasila bukan agama, tetapi substansinya mengandung dan sejalan dengan nilainilai ajaran Islam. Dengan demikian, dapat dinyatakan bahwa Pancasila itu Islami karena substansi pada setiap silanya selaras dengan nilai-nilai ajaran Islam. Dalam Pancasila terkandung ciri keislaman dan keindonesiaan yang memadukan nilai-nilai ketuhanan dan kemanusiaan (humanisme religius), hubungan individu dan masyarakat, kerakyatan dan permusyawaratan, serta keadilan dan kemakmuran (Nasri dkk, 2012: 380). Melalui proses integrasi keislaman dan keindonesiaan yang positif itu, umat Islam Indonesia sebagai kekuatan mayoritas dapat menjadi teladan yang baik (uswah hasanah) dalam mewujudkan cita-cita nasional yang sejalan dengan idealisasi Baldatun Thayyibatun wa Rabbun Ghafûr.

b. Penanganan Gerakan Radikalisme

i. Muhammadiyah telah banyak melakukan program pencegahan paham radikalisme mereka masingmasing di internal organisasi mereka. Namun, secara spesifik masih diperlukan pendalaman pemahaman tentang konsep dan praksis gerakan radikalisme yang berkembang saat ini.

ii. Dalam menyelesaikan fenomena munculnya gagasan dan tindakan radikal, ekstrem, dan teror di Indonesia, menurut catatan Komnas HAM RI masih terjadi pelanggaranpelanggaran Hak Asasi Manusia (HAM). Ipek Demirsu (2017) "mengangankan" bahwa penanggulangan gagasan dan tindakan radikal, ekstrem, dan teror dapat mengindahkan HAM dan berpegang pada prinsip due process of law dan asas praduga tak bersalah.

iii. Oleh karena itu, penanganannya harus mengacu pada perlakuan adil kepada seluruh aspek yang terkait dengan kejahatan radikalisme/terorisme tersebut, dengan prinsip sebagai berikut:

1) Penegakan hukum dan HAM serta taat pada asas praduga tak bersalah, sehingga tidak terjadi "kekerasan sekunder" pada saat penanganan pelaku kejahatan radikalis/ teroris.

2) Tidak mendeskreditkan individu dan kelompok tertentu berdasarkan sikap apriori, khususnya kepada umat Islam dengan sebuah penilaian negatif atas kejahatan radikelasme/terorisme tersebut.

3) Tidak ada persekusi atas kelompok Islam ketika terjadi tindak kekerasan. Radikalisme dan 
terorisme adalah tindakan kriminal umum dan murni, sehingga penanganannya juga diarahkan kepada seluruh pelakunya, dari kelompok mana pun, sehingga tidak tebang pilih hanya kepada umat Islam saja.

4) Tidak membenturkan pelaku kejahatan terorisme, khususnya dari oknum umat Islam, dengan idelologi negara, Pancasila, karena secara umum radikalisme/ terorisme yang terjadi di Indonesia bukan merupakan "aktivitas politik" untuk melawan ideologi negara, melainkan bentuk "perlawanan" atas perilaku ketidakadilan oleh sebagian aparat negara.

5) Menghormati dan menghargai sekecil apapun kritik dan masukan dari masyarakat atas penanganan kejahatan radikalisme/terorisme, serta tidak apriori atas berbagai masukan kepada aparat negara. Persepsi yang salah tersebut juga berimplikasi langsung pada ketidakadilan dalam penanganan aksi-aksi kekerasan ekstrem yang menjadi teror oleh kelompok lain kepada umat Islam, seperti penyerangan dan pembakaran masjid, serta penyerangan ulama dan tokoh umat Islam.

Dengan materi pokok yang disampaikan dalam Training of Trainer diharapkan peserta dan komunitas Pimpinan Ranting Muhammadiyah di Desa Bangunjiwo, Desa Banguntapan, dan Desa Sidokarto dapat memilih pemahaman dan sikap sebagai berikut:

a. Komunitas PRM Bangunjiwo Barat, PRM Banguntapan IV (Kabupaten Bantul) dan PRM Sidokarto (Kabupaten Sleman) memiliki pemahaman dan sikap bahwa organisasi Muhammadiyah menegaskan bahwa Pancasila sebagai dasar Negara Republik Indonesia,
Pancasila bukan agama tetapi substansinya mengandung dan sejalan dengan nilai-nilai ajaran Islam. Muhammadiyah berkomitmen untuk terus berjuang memproyeksikan Indonesia menjadi Negara Pancasila yang maju, adil, makmur, bermartabat, dan berdaulat dalam lindungan Allah SWT. Dengan komitmen ini, menegaskan bahwa radikalisme/terorisme bukan pilihan gerakan Muhammadiyah dan karena itu agenda pencegahan radikalisme juga menjadi kepedulian Muhammadiyah.

b. Dengan komitmen di atas, sebagai warga negara yang baik harus ikut serta melakukan bela negara dengan mencegah dan menghadapi gerakan radikalisme di masyarakat sesuai dengan kewajiban masyarakat menurut UUD 1945, Pasal 30 ayat (1) Tiap-tiap warga negara berhak dan wajib ikut serta dalam usaha pertahanan dan keamanan negara; (2) Usaha pertahanan dan keamanan negara dilaksanakan melalui sistem pertahanan dan keamanan rakyat semesta oleh Tentara Nasional Indonesia dan Kepolisian Negara Republik Indonesia, sebagai kekuatan utama, dan rakyat, sebagai kekuatan pendukung. Bela Negara dalam hal ini adalah sikap dan perilaku warga negara yang dijiwai oleh kecintaannya kepada Negara Kesatuan Republik Indonesia yang berdasarkan Pancasila dan UUD 1945 dalam menjalin kelangsungan hidup bangsa dan negara yang seutuhnya dengan melakukan pencegahan gerakan radikalisme di desa masing-masing komunitas.

\section{Rencana Tindak Lanjut}

Melalui program pengabdian ini diharapkan mitra program (PRM Bangunjiwo Barat, PRM Sidokarto, dan PRM Banguntapan IV) memiliki kemampuan dalam deteksi dini adanya gerakan radikalisme dan mampu lakukan lagnkah pencegahan agar radikalisme tidak 
berkembang di lingkungan Desa Bangunjiwo, Desa Sidokarto dan Desa Banguntapan.

\section{KESIMPULAN DAN SARAN}

\section{Kesimpulan}

1. Pelatihan Pencegahan Radikalisme melalui Penanaman Ideologi Pancasila dan Budaya Sadar Konstitusi dilakukan di 3 tempat, yakni: PRM Bangunjiwo Barat, PRM Banguntapan IV dan PRM Sidokarto. Pelatihan ini memfokuskan pada penguatan pemahaman Pancasila dan budaya sadar konstitusi serta strategi pencegahan radikalisme di Indonesia.

2. ToT Pencegahan Radikalisme melalui Penanaman Ideologi Pancasila dan Budaya Sadar Konstitusi ditujukan untuk melakukan pendalaman materi radikalisme dan pemahaman UUD 1945. Training of Trainer ini merupakan lanjutan dari pelatihan pada PRM yang dilakukan sebelumnya. Adapaun materi dalam ToT ini meliputi: Pemahaman Ideologi Bernegara Menurut Muhammadiyah dan Sikap Bernegara Muhammadivah; Pencegahan Radikalisme melalui Kewajiban Bela Negara dalam kehidupan beragama; Advokasi Kebijakan dan Hukum terkait Gerakan Radikalisme. ToT ini dilakukan agar peserta memiliki kemampuan untuk menjadi pelatih dalam agenda dan isu yang sama pada lingkup PRM Bangunjiwo Barat, PRM Sidokarto dan PRM Banguntapan IV.

3. Komunitas PRM Bangunjiwo Barat, PRM Banguntapan IV (Kabupaten Bantul) dan PRM Sidokarto (Kabupaten Sleman) memiliki pemahaman dan sikap bahwa radikalisme/ terorisme harus dicegah sedemikian rupa dengan berbagai kegiatan pencegahan sebagai bentuk bela negara warga negara yang baik demi menjalin kelangsungan hidup bangsa dan negara yang seutuhnya dengan melakukan pencegahan gerakan radikalisme di desa masing-masing komunitas.

\section{Saran}

1. Perlu adanya kerjasama di berbagai elemen di Desa Bangunjiwo, Desa Sidokarto dan Desa Banguntapan untuk gerakan pencegahan radikalisme yang dimotori oleh PRM.

2. Perlu adanya pelatihan dan sosialisasi berkelanjutan guna meningkatkan pemahaman masyarakat desa tentang fenomena radikalisme dan cara penanggulangannya.

\section{UCAPAN TERIMA KASIH}

Pada kesempatan ini, kami mengucapkan terimakasih kepada:

1. Pimpinan Ranting Muhammadiyah Bangunjiwo Barat

2. Pimpinan Ranting Muhammadiyah Banguntapan IV

3. Pimpinan Ranting Muhammadiyah PRM Sidokarto.

\section{DAFTAR PUSTAKA}

Asrori, A. (2015). Radikalisme Di Indonesia: Antara Historisitas dan Antropisitas. Kalam, 9(2), 253-268.

Damayanti, N. P., Thayibi, I., Gardhiani, L. A., \& Limy, I. (2003). Radikalisme Agama Sebagai Salah Satu Bentuk Perilaku Menyimpang: Studi Kasus Front Pembela Islam. Indonesian Journal of Criminology, 3(1).

Hilmy, M. (2015). Radikalisme Agama Dan Politik Demokrasi Di Indonesia Pasca-Orde Baru. MIQOT: Jurnal Ilmu-ilmu Keislaman, 39(2).

Imran Nasri dkk. (2012). Manhaj Gerakan Mubammadiyah Ideologi, Kbittah, dan Langkah. Suara Muhammadiyah: Yogyakarta.

Khamdan, M. (2016). Pengembangan Nasionalisme Keagamaan Sebagai Strategi Penanganan Potensi Radikalisme Islam Transnasional. Addin, 10(1), 207-232.

Kusumasari, B., \& Suyatna, H. Peningkatan Kapabilitas Pemasaran Pascabencana 
Bagi Perempuan Hunian Tetap Pager Jurang, Sleman, Yogyakarta. Jurnal Pengabdian kepada Masyarakat (Indonesian Journal of Community Engagement), 1(1), 14-23.

Latif, Y. (2015). Negara Paripurna: Historitas, Rasionalitas dan Aktualitas Pancasila. Gramedia Pustaka Utama: Jakarta.

Lola Loveita. (2017). Radikalisme Agama Di Indonesia: Urgensi Negara Hadir Dan Kebijakan Publik Yang Efektif. International NGO Forum on Indonesian Development: Jakarta

Muhammadiyah, P. P. (2015). Tanfidz Keputusan Muktamar Mubammadiyah ke 47. Berita Resmi Muhammadiyah: Yogyakarta.

Rokhmad, A. (2012). Radikalisme Islam dan Upaya Deradikalisasi Paham Radikal. Walisongo: Jurnal Penelitian Sosial Keagamaan, 20(1), 79-114.

Widjajanti, K. (2011). Model pemberdayaan masyarakat. Jurnal Ekonomi Pembangunan: Kajian Masalah Ekonomi dan Pembangunan, 12(1), 15-27. 